\title{
SPRING BARLEY YIELD PARAMETERS AFTER LIGNITE, SODIUM HUMATE AND NITROGEN UTILIZATION
}

\author{
PETER KOVÁČIK ${ }^{1 *}$, ALŽBETA ŽOFAJOVÁ2 ${ }^{2}$, VLADIMÍR ŠIMANSKÝ ${ }^{3}$, \\ KLAUDIA HALÁSZOVÁ ${ }^{4}$
}

${ }^{1,3,4}$ Slovak University of Agriculture in Nitra, Slovak Republic

${ }^{2}$ National Agricultural and Food Centre - Research Institute of Plant Production, Piešt'any, Slovak Republic

KOVÁČIK, P. - ŽOFAJOVÁ, A. - ŠIMANSKÝ, V. - HALÁSZOVÁ, K.: Spring barley yield parameters after lignite, sodium humate and nitrogen utilization. Agriculture (Pol'nohospodárstvo), vol. 62, 2016, no. 3, p. 80-89.

The existence of a small number of publications dealing with the impact of solid sodium humate and lignite on the quantity and quality of grown crops was the reason for establishing the field experiment. The objective of this experiment was to detect the impact of solid lignite and solid sodium humate on the quantity and quality of spring barley yield. These substances were applied into the soil either independently or along with nitrogen fertiliser. The next objective was to determine the impact of foliar application of sodium humate water solution applied either independently or along with nitrogen fertiliser on the quality and quantity of spring barley yield. The achieved results showed that the autumn application of solid lignite and the presowing application of solid sodium humate into the soil tended to decrease the yield of both grain and straw of spring barley, crude protein content in grain, proportion of the first-class grains and volume weight of grain, whereas the impact of humate was more negative. Lignite and sodium humate in the solid form should be used along with nitrogen fertiliser. The application of sodium humate in liquid form during the growth season of barley tended to increase the yield of both grain and straw. The joint application of nitrogen and liquid sodium humate during the growth season of barley increased the grain yield of barley significantly. A lower dose of nitrogen, applied during the growth season of barley (growth season $\mathrm{BBCH} 23$ ), increased the grain yield of barley considerably more than a higher $\mathrm{N}$ dose, applied into the soil before barley sowing.

Key words: lignite, Lignofert, sodium humate, coal materials, spring barley

In Slovakia, the supply of humus creating material into soil (manure, postharvest residues, etc.) has fallen dramatically in the last 25 years. As a result, the yields of field crops have stagnated in many agricultural enterprises in the recent five or ten years, in spite of the growth of commercial fertiliser applications. The quality of cultivated products is also diminishing. One way to solve this unfavourable situation is to utilize the substances which are rich in carbon (sawdust particles, coal materials, etc.).
However, their incorrect usage can lead to the inhibition of plant germination, growth retardation and yield decrease (Kováčik 2014). Therefore, the agricultural practice applies the materials which are rich in carbon only by foliar application, in particular, in gram and kilogram quantities per hectare. They have the stimulating effect on the plant growth, but they do not have any impact on carbon content in soil, which hereafter limits the yield quantity and quality. The usage of solid coal materials (dust of bituminous,

Prof. Ing. Peter Kováčik, CSc. (*Corresponding author), Slovak University of Agriculture in Nitra, Faculty of Agrobiology and Food Resources, Department of Agrochemistry and Plant Nutrition, Tr. A. Hlinku 2, Nitra, Slovak Republic. E-mail: Peter.Kovacik@uniag.sk

Ing. Alžbeta Žofajová, PhD., National Agricultural and Food Center, Plant Production Research Institute Piešt’any, Bratislavská cesta 122, Piešt’any, Slovak Republic

Doc. Ing. Vladimír Šimanský, PhD., Slovak University of Agriculture in Nitra, Faculty of Agrobiology and Food Resources, Department of Soil Science and Geology, Tr. A. Hlinku 2, Nitra, Slovak Republic

Doc. Ing. Klaudia Halászová, PhD., Slovak University of Agriculture in Nitra, Faculty of Horticulture and Landscape Engineering, Department of Landscape Planning and Ground Design, Tr. A. Hlinku 2, Nitra, Slovak Republic 
sub-bituminous or lignite coal, sodium humate, potassium humate, etc.), which would supply soil with substantial quantities of carbon, does not appear. In spite of that, there are many facts that give evidence of their positive impact on the yield crop parameters and their quality. The experiments of Weismann et al. (1993), Valšíková and Viteková (2006) demonstrated that after the application of $5 \mathrm{t} / \mathrm{ha}$ lignite into soil, the yields of potatoes, sugar beet, maize, spring barley and lettuce increased. Similarly, the positive results after the application of $5 \mathrm{~kg} / \mathrm{ha}$ sodium humate into the soil during spring barley cultivation were recorded by Kováčik and Fecenko (1996) and by Shalabey and Bízik (1998) during wheat cultivation. The significant yield growth after the application of the given materials into soil in solid form or dissolved in water during the cultivation of different crops, was also registered by other authors (Lee \& Bartlett 1976; Lobartini et al. 1992; Patil et al. 2011).

We took into consideration a small number of publications dealing with the impact of usage of solid coal materials on the quantity and quality of yields of cultivated crops. Therefore, we started the experiment with the target to find out the impact of solid lignite and solid sodium humate applied into soil independently, or along with nitrogen fertiliser. The objective was also to guage the impact of foliar application of water solution of sodium humate on the quantity and quality of spring barley - when applied independently and when applied along with nitrogen fertiliser.

\section{MATERIAL AND METHODS}

The field small-plot trial was carried out during two farming years (2005 and 2006) at an altitude of 320 meters above sea level in the locality of town Sabinov $\left(49^{\circ} 05^{\prime} \mathrm{N}\right.$ and $21^{\circ} 04^{\prime} \mathrm{E}$ - eastern Slovakia) on Haplic Dystric Cambisol (WRB 2006), which was typical of high acidity to acid soil $\mathrm{pH}$ and low carbon content. The agrochemical parameters of Haplic Cambisol are given in the Table 1. They were determined by the following methods: $\mathrm{N}^{-} \mathrm{NH}_{4}^{+}-$colorimertically by Nessler's

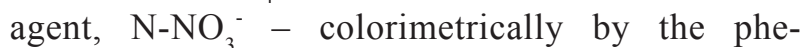

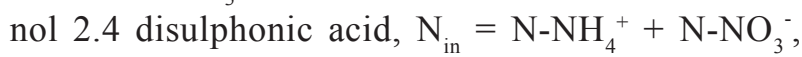

P - colorimetrically (extract Mehlich 3 - Mehlich 1984), $\mathrm{K}$ and $\mathrm{Ca}$ - by flame photometry (extract Mehlich 3 - Mehlich 1984), Mg - by atomic absorption spectrophotometry (extract Mehlich 3 - Mehlich 1984), $\mathrm{C}_{\text {ox }}$ - oxidometrically by Ťjurin in modification of Nikitin (Dziadowiec \& Gonet 1999), $\mathrm{pH} / \mathrm{KCl}$ - potentiometrically $\left(1.0 \mathrm{~mol} / \mathrm{dm}^{3}\right.$ $\mathrm{KCl})$.

In the first year of experiment, we detected acid soil reaction, and in the following year, high acidity of soil reaction was found. In both years, $2.5 \mathrm{t} / \mathrm{ha}$ $90 \%$ of $\mathrm{CaCO}_{3}$ was applied before tillage in autumn.

Solid sodium humate (black flakes) was used in the experiment. This was produced in the Czech Republic by alkalic extraction from low-cal coal, which was carbonized imperfectly from undersurface coal, called Capuchin. Lignite was of Slovak origin, and it was sold with the trade mark Lignofert. It was produced by grinding, followed by sieving of lignite through sieves of $0.1-10.0 \mathrm{~mm}$. The agrochemical and physical parameters of both tested materials are given in the Table 2 and 3 .

The model crop was spring barley, malting cultivar Nitran, sown by 4.5 million seeds per hectare, cultivated within the sowing plan after potatoes. After the harvesting of potatoes, green fertilising was carried out using winter oilseed rape.

The experiment variants, doses of lignite, sodium humate and nitrogen are given in the Table 4. This table shows that in the control variant 1 neither coal materials nor nitrogen fertilisers were used. As the only tested material, lignite was applied in autumn because it is well known that this material is relatively stable (var. 2, 6 and 10). The dose of lignite 8 $\mathrm{t} / \mathrm{ha}$ was in adherence with the knowledge about the application doses of processed coal mechanically, obtained by Weismann et al. (1993). In variant 2, lignite was applied individually, and in the variants 6 and 10, nitrogen was added to lignite in two different periods. Sodium humate was applied in two periods - before sowing and during growth season of spring barley in the same dose $10 \mathrm{~kg} / \mathrm{ha}$ (var. 3, 5,8 and 9). In the variants 3 and 8 , lignite was applied individually, and in the variants 5 and 9, it was used along with $\mathrm{N}$ fertiliser. The dose $10 \mathrm{~kg} / \mathrm{ha}$ originated from the dose of lignite ( $8 \mathrm{t} / \mathrm{ha}$ ), and the knowledge presented by Kováčik and Jasiewicz (2009) that sodium humate contains about 800 times 
more hot-water soluble carbon than Lignofert. The same quantity of hot-water soluble carbon was applied with the dose $8 \mathrm{t} / \mathrm{ha}$ of lignite as with the dose of $10 \mathrm{~kg} / \mathrm{ha}$ sodium humate.

Nitrogen was applied through the fertiliser DAM-390 containing $30 \% \mathrm{~N}$ in three forms: $7.5 \% \mathrm{~N}$ in nitrate form, $7.5 \%$ in ammonium form and $15 \%$ in amidic form. The $\mathrm{pH}$ value of the fertiliser was 7.5. In the variants 4,5 and $6, \mathrm{~N}$ was applied before sow- ing, and in the variants 7, 9 and $10, \mathrm{~N}$ was applied during barley growing season in the growth phase $\mathrm{BBCH} 23$ (tillering). The dose of nitrogen fertilisers $\left(D_{N}\right)$ in the variants 4,5 , and 6 was calculated on the basis of respecting level $\mathrm{N}_{\text {in }}$ (inorganic nitrogen) in the soil sample taken from the layer $0.0-0.6 \mathrm{~m}$ in spring (Table 1) and the necessity $\mathrm{N}$ for the planned yield $\left(\mathrm{P}_{\mathrm{N}}\right)$. According to the facts presented by Kováčik and Fecenko (1992), who have given 6 dif-

$\mathrm{T}$ a

Agrochemical parameters of Haplic Cambisol (dry matter)

\begin{tabular}{|c|c|c|c|c|c|c|c|c|c|c|c|}
\hline \multirow{2}{*}{$\begin{array}{c}\text { Layer } \\
{[\mathrm{m}]}\end{array}$} & \multirow{2}{*}{$\begin{array}{c}\text { Year of } \\
\text { experiment }\end{array}$} & $\mathrm{N}-\mathrm{NH}_{4}^{+}$ & $\mathrm{N}^{-\mathrm{NO}_{3}}{ }_{3}^{-}$ & $\mathrm{N}_{\text {in }}$ & $\mathrm{P}$ & K & $\mathrm{Ca}$ & $\mathrm{Mg}$ & \multirow{2}{*}{$\mathrm{pH} / \mathrm{KCl}$} & \multirow{2}{*}{$\begin{array}{l}\mathrm{C}_{\mathrm{ox}} \\
{[\%]}\end{array}$} & \multirow{2}{*}{$\begin{array}{c}\mathrm{N}_{\mathrm{an}} \\
\text { at BBCH } 22 \\
{[\mathrm{mg} / \mathrm{kg}]}\end{array}$} \\
\hline & & \multicolumn{7}{|c|}{$[\mathrm{mg} / \mathrm{kg}]$} & & & \\
\hline $0.0-0.3$ & \multirow{2}{*}{ first } & 9.8 & 5.2 & 15.0 & 138 & 275 & 700 & 138 & 5.41 & 1.08 & 12.4 \\
\hline $0.3-0.6$ & & 8.4 & 3.9 & 12.1 & 95 & 290 & 800 & 165 & 5.64 & 0.73 & 10.1 \\
\hline $0.0-0.3$ & \multirow{2}{*}{ second } & 9.8 & 4.1 & 13.9 & 123 & 353 & 1,000 & 163 & 4.63 & 1.14 & 13.3 \\
\hline $0.3-0.6$ & & 8.3 & 4.0 & 12.3 & 81 & 203 & 1,225 & 198 & 4.98 & 0.82 & 9.5 \\
\hline
\end{tabular}

$\mathrm{T}$ a

Agrochemical parameters of sodium humate and lignite (dry matter)

\begin{tabular}{|c|c|c|c|c|c|c|c|c|c|c|}
\hline \multirow{2}{*}{ Material } & $\mathrm{N}-\mathrm{NH}_{4}^{+}$ & $\mathrm{N}-\mathrm{NO}_{3}^{-}$ & $\mathrm{N}_{\text {in }}$ & $\mathrm{P}$ & $\mathrm{K}$ & $\mathrm{Ca}$ & $\mathrm{Mg}$ & \multirow{2}{*}{$\mathrm{pH} / \mathrm{KCl}$} & \multirow{2}{*}{$\begin{array}{l}\mathrm{C}_{\text {ox }} \\
{[\%]}\end{array}$} & \multirow{2}{*}{$\begin{array}{c}\mathrm{EC} \\
{[\mathrm{mS} / \mathrm{cm}]}\end{array}$} \\
\hline & \multicolumn{7}{|c|}{$[\mathrm{mg} / \mathrm{kg}]$} & & & \\
\hline Sodium humate & 3,125 & 6.5 & 3,132 & 165 & 27,250 & 52,000 & 2,840 & 9.66 & 45.0 & 13.87 \\
\hline Lignite & 11.1 & 1.6 & 12.7 & traces & 75 & 2,750 & 908 & 5.35 & 30.7 & 2.62 \\
\hline
\end{tabular}

$\mathrm{T}$ a

Size fractions of sodium humate and lignite (Lignofert)

\begin{tabular}{|c|c|c|}
\hline \multirow{2}{*}{$\begin{array}{c}\text { Size fraction } \\
{[\mathrm{mm}]}\end{array}$} & Sodium humate & Lignite \\
\cline { 2 - 3 }$>7$ & \multicolumn{2}{|c|}{$[\%]$} \\
\hline 5 & 0.19 & 4.80 \\
$>3$ & 0.38 & 9.66 \\
$>1$ & 2.67 & 17.68 \\
$>0.5$ & 23.87 & 20.97 \\
$>0.25$ & 33.67 & 14.65 \\
$<0.25$ & 19.09 & 9.43 \\
& 20.12 & 22.80 \\
\hline
\end{tabular}


ferent effective approaches for the calculation of $\mathrm{N}$ dose for spring barley, it was calculated for $100 \%$ usage of nitrogen, which occurs in the layer $0.0-0.6 \mathrm{~m}$, and the requirement of $24 \mathrm{~kg}$ of $\mathrm{N}$ per 1 tonne of the main product and the respective quantity of a by-product. The planned yield was $6 \mathrm{t} / \mathrm{ha}$. $\mathrm{N}$ dose was calculated using the formula given below:

$$
\mathrm{D}_{\mathrm{N}}=\mathrm{P}_{\mathrm{N}}-\mathrm{N}_{\text {in }} \times 9
$$

where: $\mathrm{P}_{\mathrm{N}}=$ necessity of $\mathrm{N}$ for the planned yield, $\mathrm{N}_{\text {in }}$ $=$ the content of inorganic nitrogen in the soil sample taken from the layer $0.0-0.6 \mathrm{~m}$ in spring. The number 9 is the coefficient of recount from unit $\mathrm{mg} / \mathrm{kg}$ to unit $\mathrm{kg} / \mathrm{ha}$. The coefficient was determined by soil layer $(0.6 \mathrm{~m})$ and volume weight of soil in the particular layer $\left(1.5 \mathrm{~g} / \mathrm{cm}^{3}\right)$.

In the variants $7,8,9$ and 10 , the soil samples were taken from the layer $0.0-0.6 \mathrm{~m}$ in the growth phase of spring barley BBCH 22 (tillering) and $\mathrm{N}_{\text {in }}$ content was determined. At the same time the aboveground phytomass was taken in order to specify $\mathrm{N}$ content in it. The quantity of nitrogen (in $\mathrm{kg} / \mathrm{ha}$ ) taken in by vegetation was calculated. Based on the data obtained, the $\mathrm{N}$ dose was calculated according to the following formula:

$$
\mathrm{D}_{\mathrm{N}}=\mathrm{P}_{\mathrm{N}}-\mathrm{N}_{\mathrm{s}}-\mathrm{N}_{\mathrm{p}},
$$

where: $\mathrm{D}_{N}$ is $\mathrm{N}$ dose, $\mathrm{P}_{\mathrm{N}}$ is $\mathrm{N}$ needed for planned yield and $\mathrm{N}_{\mathrm{s}}$ is nitrogen $(\mathrm{kg} / \mathrm{ha})$ in soil in the layer $0.0-0.6 \mathrm{~m}\left(\mathrm{~N}_{\mathrm{an}}\right.$ as $\left.\mathrm{mg} / \mathrm{kg} \times 9\right)$.

We assumed $100 \%$ utilization of nitrogen and $\mathrm{N}_{\mathrm{p}}$ meant nitrogen in a plant. In the growth phase, there was $22.7 \mathrm{~kg} / \mathrm{ha} \mathrm{N}$ of BBCH 22 in the barley plants in the first year of the experiment and $21.3 \mathrm{~kg} / \mathrm{ha} \mathrm{N}$ in the second year. The analyses and calculation were accomplished in the course of five days because it was necessary to apply $\mathrm{N}$ fertilisers after sampling as soon as possible.

The experiment was established using the splitplot design as fully randomised blocks in three replications. The area of one plot was $21 \mathrm{~m}^{2}(1.5 \mathrm{~m} \times$ $14 \mathrm{~m})$. The harvest was carried out manually in the following way - the whole aboveground phytomass was taken from the area $1 \mathrm{~m}^{2}$ in the period of technological ripeness of barley from each plot. The yield of grain and straw were evaluated. In grain,

T a

\begin{tabular}{|c|c|c|c|c|c|c|c|c|c|c|c|}
\hline \multirow{3}{*}{\multicolumn{2}{|c|}{ Variant }} & \multicolumn{5}{|c|}{ First year of experiment } & \multicolumn{5}{|c|}{ Second year of experiment } \\
\hline & & \multicolumn{3}{|c|}{ before growing season } & \multicolumn{2}{|c|}{$\begin{array}{l}\text { at the time of } \\
\text { growing season }\end{array}$} & \multicolumn{3}{|c|}{ before growing season } & \multicolumn{2}{|c|}{$\begin{array}{l}\text { at the time of } \\
\text { growing season }\end{array}$} \\
\hline & & \multirow{2}{*}{$\begin{array}{r}\text { lignite } \\
{[\mathrm{t} / \mathrm{ha}]}\end{array}$} & $\begin{array}{l}\text { sodium } \\
\text { humate }\end{array}$ & $\mathrm{N}$ & humate & $\mathrm{N}$ & \multirow{2}{*}{$\begin{array}{c}\text { lignite } \\
{[\mathrm{t} / \mathrm{ha}]}\end{array}$} & $\begin{array}{l}\text { sodium } \\
\text { humate }\end{array}$ & $\mathrm{N}$ & $\begin{array}{l}\text { sodium } \\
\text { humate }\end{array}$ & $\mathrm{N}$ \\
\hline designation & number & & \multicolumn{4}{|c|}{$[\mathrm{kg} / \mathrm{ha}]$} & & \multicolumn{4}{|c|}{$[\mathrm{kg} / \mathrm{ha}]$} \\
\hline 0 & 1 & - & - & - & - & - & - & - & - & - & - \\
\hline $\operatorname{Lig}_{\text {Aut }}$ & 2 & 8 & - & - & - & - & 8 & - & - & - & - \\
\hline Hum $_{\text {Sow }}$ & 3 & - & 10 & - & - & - & - & 10 & - & - & - \\
\hline $\mathrm{N}_{\text {Sow }}$ & 4 & - & - & 22 & - & - & - & - & 26 & - & - \\
\hline $\mathrm{Hum}_{\text {Sow }}+\mathrm{N}_{\text {Sow }}$ & 5 & - & 10 & 22 & - & - & - & 10 & 26 & - & - \\
\hline $\operatorname{Lig}_{\text {Aut }}+\mathrm{N}_{\text {Sow }}$ & 6 & 8 & - & 22 & - & - & 8 & - & 26 & - & - \\
\hline $\mathrm{N}_{\mathrm{BBCH} 23}$ & 7 & - & - & - & - & 20 & - & - & - & - & 20 \\
\hline $\mathrm{Hum}_{\mathrm{BBCH} 23}$ & 8 & - & - & - & 10 & - & - & - & - & 10 & - \\
\hline $\mathrm{Hum}_{\mathrm{BBCH} 23}+\mathrm{N}_{\mathrm{BBCH} 23}$ & 9 & - & - & - & 10 & 20 & - & - & - & 10 & 20 \\
\hline $\operatorname{Lig}_{\text {Aut }}+\mathrm{N}_{\mathrm{BBCH} 23}$ & 10 & 8 & - & - & - & 20 & 8 & - & - & - & 20 \\
\hline
\end{tabular}

Variants of experiment and dosages of tested materials

0 - control; Lig $_{\text {Aut }}-$ lignite in autumn; Hum Sow $_{-}$humate before of sowing; $\mathrm{N}_{\text {Sow }}-$ nitrogen before sowing; Hum $_{\text {Sow }}+\mathrm{N}_{\text {Sow }}$ - humate and nitrogen before sowing; $\operatorname{Lig}_{\text {Aut }}+\mathrm{N}_{\text {Sow }}$ - lignite in autumn and nitroben before sowing; $\mathrm{N}_{\mathrm{BBCH} 23}$ - nitrogen in growth phase of $\mathrm{BBCH} 23$; Hum ${ }_{\mathrm{BBCH} 23}$ - humate in growth phase of $\mathrm{BBCH} 23$; $\mathrm{Hum}_{\mathrm{BBCH} 23}+\mathrm{N}_{\mathrm{BBCH} 23}$ - humate and nitrogen in growth phase of $\mathrm{BBCH} 23 ; \mathrm{Lig}_{\mathrm{Aut}}+\mathrm{N}_{\mathrm{BBCH}_{23}}$ - lignite in autumn and nitrogen in growth phase of $\mathrm{BBCH} 23$ 
the content of crude protein and weight of one thousand grains (TKW - thousand kernel weight), the proportion of the first-class grain and the volume weight and nutrient content ( $\mathrm{N}, \mathrm{P}, \mathrm{K}, \mathrm{Ca})$ was determined. In order to determine the nutrient content, the methods published in Kováčik (1997) were used. Crude protein content was calculated according to the formula $6.25 \times \% \mathrm{~N}$. The obtained results were processed using the mathematical and statistical methods, namely, analysis of variance (ANOVA) and linear regression analysis using Statgraphics PC software, version 5.0.

\section{RESULTS AND DISCUSSION}

The autumn application of lignite and the pre-sowing application of sodium humate tended to decrease the yield of grain and straw of spring barley. Here the impact of humate was more negative, and it was statistically insignificant (var. 2 and 3, Table 5). In the variant (var. 3) where sodium humate was used, the absolutely lowest yield of grain and straw was achieved out of the 10 variants in the experiment. The negative impact of sodium humate and lignite on the yield of barley grain and straw, which was recorded in the experiment, did not correspond with the facts published by Halčínová and Kováčik (2011), who recorded 12.6 and $11 \%$ increase of grain yield after the application of lignite and humate in the doses $900 \mathrm{~kg} / \mathrm{ha}$ and $300 \mathrm{~kg} / \mathrm{ha}$.

The presowing $\mathrm{N}$ application in the dose, which took cognizance of $\mathrm{N}_{\text {in }}$ in soil, increased the yield of grain and straw as compared to the control variant, however, only insignificantly (Table 5, var. 4). The unimportant yield growth after the application of $\mathrm{N}$ fertilisers did not correspond to the opinion of many authors who claimed that after presowing, the fertilisation of spring barley yields increased significantly, often by $30 \%$ or more (Užík et al. 2009; Šrek \& Kunzová 2011; Chen et al. 2016). On the contrary, N application carried out during barley growth season (BBCH 23) evidently resulted in the highest yields of grain and straw out of all the variants (var. 7). The recorded higher growth of spring barley yield after $\mathrm{N}$ application during the growth season as compared with presowing $\mathrm{N}$ fertilisation is identical with the findings of several authors (Kováčik et al. 2006; Škarpa 2006; Candráková et al. 2009). Because of the frequent significant increase of contents of crude

$\mathrm{T}$ a

The impact of lignite, sodium humate and nitrogen on the spring barley yield parameters (average of two years)

\begin{tabular}{|c|c|c|c|c|c|c|}
\hline \multicolumn{2}{|c|}{ Variant } & Grain & Straw & $\begin{array}{l}\text { Crude } \\
\text { protein }\end{array}$ & $\begin{array}{c}\text { Grain of the } 1^{\text {st }} \\
\text { class }\end{array}$ & \multirow{2}{*}{$\begin{array}{c}\text { Volume weight } \\
{[\mathrm{g} / \mathrm{l}]}\end{array}$} \\
\hline designation & number & \multicolumn{2}{|c|}{$[\mathrm{t} / \mathrm{ha}]$} & \multicolumn{2}{|c|}{$[\%]$} & \\
\hline 0 & 1 & $4.63^{\mathrm{ab}}$ & $3.64^{\mathrm{ab}}$ & $9.51^{\mathrm{b}}$ & $78.87^{\mathrm{abc}}$ & $741.00^{\mathrm{ab}}$ \\
\hline $\operatorname{Lig}_{\text {Aut }}$ & 2 & $4.54^{\mathrm{ab}}$ & $3.57^{\mathrm{ab}}$ & $9.31^{\mathrm{ab}}$ & $77.57^{\mathrm{ab}}$ & $737.33^{\mathrm{a}}$ \\
\hline Hum $_{\text {Sow }}$ & 3 & $4.35^{\mathrm{a}}$ & $3.44^{\mathrm{a}}$ & $9.10^{\mathrm{ab}}$ & $77.30^{\mathrm{a}}$ & $738.50^{\mathrm{ab}}$ \\
\hline $\mathrm{N}_{\text {Sow }}$ & 4 & $4.82^{b}$ & $3.72^{\mathrm{abc}}$ & $9.34^{\mathrm{ab}}$ & $79.76^{\mathrm{cd}}$ & $741.11^{\mathrm{ab}}$ \\
\hline $\mathrm{Hum}_{\text {Sow }}+\mathrm{N}_{\text {Sow }}$ & 5 & $4.80^{\mathrm{bc}}$ & $3.66^{\mathrm{ab}}$ & $9.26^{\mathrm{ab}}$ & $80.17^{\mathrm{cd}}$ & $742.09^{\mathrm{ab}}$ \\
\hline $\operatorname{Lig}_{\text {Aut }}+\mathrm{N}_{\text {Sow }}$ & 6 & $4.88^{\mathrm{bc}}$ & $3.66^{\mathrm{ab}}$ & $9.27^{\mathrm{ab}}$ & $81.30^{\mathrm{d}}$ & $742.83^{\mathrm{ab}}$ \\
\hline $\mathrm{N}_{\mathrm{BBCH} 23}$ & 7 & $5.14^{\mathrm{c}}$ & $3.98^{\mathrm{c}}$ & $9.56^{\mathrm{b}}$ & $80.47^{\mathrm{cd}}$ & $744.17^{\mathrm{b}}$ \\
\hline $\mathrm{Hum}_{\mathrm{BBCH} 23}$ & 8 & $4.71^{\mathrm{ab}}$ & $3.67^{\mathrm{a}}$ & $8.96^{\mathrm{a}}$ & $78.93^{\mathrm{abc}}$ & $741.09^{\mathrm{ab}}$ \\
\hline $\mathrm{Hum}_{\mathrm{BBCH} 23}+\mathrm{N}_{\mathrm{BBCH} 23}$ & 9 & $5.06^{\mathrm{c}}$ & $3.83^{\mathrm{bc}}$ & $9.37^{\mathrm{ab}}$ & $80.43^{\mathrm{cd}}$ & $742.65^{\mathrm{ab}}$ \\
\hline $\operatorname{Lig}_{\text {Aut }}+\mathrm{N}_{\mathrm{BBCH} 23}$ & 10 & $5.09^{c}$ & $3.85^{\mathrm{bc}}$ & $9.41^{\mathrm{ab}}$ & $79.37^{\mathrm{bc}}$ & $741.83^{\mathrm{ab}}$ \\
\hline$L S D_{005}$ & & 0.368 & 0.295 & 0.465 & 1.864 & 6.409 \\
\hline
\end{tabular}

$L S D_{0.05}$ - least significant difference at the level a $=0.05$ ( $L S D$ test); different letter behind a numerical value indicate statistically significant difference at the level $95.0 \%$

Explanation: See Table 4 
proteins in spring barley grain after the $\mathrm{N}$ application during growth season, several authors do not recommend fertilisation of spring barley during the growth season (Cook 1982; Kandera 1994). Užík and Žofajová (2006) pointed out that it is important to adapt spring barley fertilisation to the cultivar requirements.

The solo application of sodium humate in the form of water solution (var. 8) carried out in the growth phase of barley BBCH 23, unlike the presowing application of the solid humate (var. 3), did not have a negative impact on the yield of grain and straw (Table 4). This fact refers to the sensitivity of germinating barley plants, or young barley plants to the presowing application of the solid sodium humate, which is typical of a high value of electrical conductivity (Table 2). Thus, as the autumn lignite application is recommended, similarly, the application of the solid humates should be carried out much in advance, before the crop sowing.

The presowing nitrogen application into soil, which contained coal materials (var. 5 and 6), had a positive impact on the grain and straw yield in comparison with the control variant. However, the difference was not significant. In spite of the fact that the solo applications of lignite and humate did not increase grain yield (var. 2 and 3), a higher grain yield was achieved by the joint application of lignite and nitrogen (var. 6), as compared to the solo nitrogen application (var. 4). This finding proved the negative impact of solid sodium humate application into soil on the barley grain yield recorded in the variant 3 .

The pre-sowing addition of nitrogen to the coal materials did not bring a higher straw yield in relation to the $\mathrm{N}$ application itself (var. 5 and 6 versus var. 4).

The nitrogen fertilisation in the growth phase $\mathrm{BBCH} 23$ (var. 7, 9 and 10) resulted in a higher grain and straw yield, regardless of the application of $\mathrm{N}$ on the plants cultivated on soil treated or untreated by lignite or sodium humate. The comparison of the grain and straw yields between variant 7 and the variants 9 and 10 confirmed the negative impact of coal materials on the quantity of spring barley yield, where humate had more negative effect than lignite.

The evaluation of impact of tested materials and studying the crude protein content in spring barley grain, detected that the lowest content of crude protein was recorded in variants where only sodium humate had been applied (var. 8 and 3). Amongst all the nine treated variants of the experiment, the content of nitrogen substances decreased in all but one variant, where nitrogen was applied on barley leaves during the growth season (var. 7). The detected negative impact of coal material on the content of crude protein in grain can be evaluated as a positive effect if barley is grown on soils rich in total and organic nitrogen because barley, which is grown on these soils, usually achieves excess content of crude protein. The drop of crude protein level as a positive effect of humate was also presented by Fecenko et al. (1995).

In the experiment, in all the variants, crude protein contents were lower than $10 \%$. Therefore, the decrease of crude protein level after the application of coal materials was evaluated as a negative impact leading to the worse qualitative parameter of spring barley grain grown for malty purposes.

No significant relation was determined between the crude protein level and grain yield, the crude protein and straw yield, the crude protein and the proportion of the first-class grain and the volume weight of grain (Table 6).

The smallest proportion of the first-class grains and also the lowest volume weight of grains were registered in the variants where the solo application of lignite and humate was carried out into soil (var. 2 and 3). These facts along with the impact of solo applications of coal materials recorded till date proves unambiguously that in this experiment, the usage of solid lignite and solid sodium humate tended to decrease the quantity as well as quality of spring barley.

The pre-sowing nitrogen applications and $\mathrm{N}$ applications in the growth phase $\mathrm{BBCH} 23$ carried out independently, or the nitrogen applications on the variants treated by coal materials - all these measures increased the proportion of the first-class grains (var. $4,5,6,8,9,10$ ). The statistically significant increase of the proportion of first-class grains in comparison with the control variant was recorded only in variant 6 . In this variant, lignite was applied into soil in autumn and nitrogen before sowing. Along with an increase in the proportion of first-class grains in the variants where nitrogen was 
applied apart from coal materials, there was an increase of grain yield also recorded in those variants. This fact means it is necessary to simultaneously apply lignite or humate with the nitrogen fertiliser.

The impact of experiment variants on the bulk density of soil was comparable with the impact of variants on the proportion of first-class grains, which can be proved by the correlation coefficient $r=0.9096^{++}$between the first-class grains and the volume weight of grain.

The application of the soil additive substances, the different biostimulants can often result in a higher yield with a lower content of nutrients, and a lower quantity of the content substances (Bielek 1998). The Table 7 shows that the tested coal materials had a negative impact on the contents of phosphorus and potassium in grain of spring barley. The partially different findings were achieved by Halčínová and Kováčik (2011), who did not record a significant change after the application of solid lignite and sodium humate in the content of $\mathrm{P}$ and $\mathrm{K}$ in barley grain.

In the presented experiment, a decrease in phosphorus contents was also seen in the variants where only nitrogen was applied without coal materials (var. 4 and 7). This fact confirms the information provided by Vaneková and Vanek (1983), Gill and Lavender (1983), who claimed that along with an increase in the application dose of nitrogen, there usually is a falls in the phosphorus content in a plant.

$\mathrm{T}$ a

Correlation coefficient $r$ expressing the relationship between the crude protein content and some quantitative and qualitative parameters of barley yield

\begin{tabular}{|l|l|c|}
\hline Dependent parameter & Independent parameter & Correlation coefficient $(r)$ \\
\hline Crude protein & grain & $0.535^{\text {ns }}$ \\
Crude protein & straw & $0.610^{\text {ns }}$ \\
Crude protein & grain of the $1^{\text {st }}$ class & $0.350^{\text {ns }}$ \\
Crude protein & volume weight & $0.412^{\text {ns }}$ \\
\hline
\end{tabular}

ns - non significant $(n=10)$

$\mathrm{T}$ a

The impact of lignite, sodium humate and nitrogen application on the content of $\mathrm{P}, \mathrm{K}$ and $\mathrm{Ca}$ in spring barley grains (dry mater - average of two years)

\begin{tabular}{|c|c|c|c|c|}
\hline \multicolumn{2}{|c|}{ Variant } & $\mathrm{P}$ & K & $\mathrm{Ca}$ \\
\hline designation & number & \multicolumn{3}{|c|}{$[\mathrm{mg} / \mathrm{kg}]$} \\
\hline 0 & 1 & $4,206.3^{f}$ & $5,242.7^{\mathrm{e}}$ & $564.0^{\mathrm{a}}$ \\
\hline $\operatorname{Lig}_{\text {Aut }}$ & 2 & $3,923.7^{\mathrm{cd}}$ & $4,974.3^{\mathrm{abc}}$ & $562.0^{\mathrm{a}}$ \\
\hline Hum $_{\text {Sow }}$ & 3 & $3,956.0^{\mathrm{cd}}$ & $4,939.7^{\mathrm{ab}}$ & $568.0^{\mathrm{a}}$ \\
\hline $\mathrm{N}_{\text {Sow }}$ & 4 & $4,100.0^{\mathrm{e}}$ & $5,248.0^{\mathrm{e}}$ & $520.0^{\mathrm{a}}$ \\
\hline $\mathrm{Hum}_{\text {Sow }}+\mathrm{N}_{\text {Sow }}$ & 5 & $3,886.0^{\mathrm{bc}}$ & $5,146.7^{\mathrm{de}}$ & $534.0^{\mathrm{a}}$ \\
\hline $\operatorname{Lig}_{\text {Aut }}+\mathrm{N}_{\text {Sow }}$ & 6 & $3,824.3^{\mathrm{ab}}$ & $5,066.3^{\mathrm{bcd}}$ & $528.0^{\mathrm{a}}$ \\
\hline $\mathrm{N}_{\mathrm{BBCH} 23}$ & 7 & $3,768.0^{\mathrm{a}}$ & $5,094.0^{\mathrm{cd}}$ & $522.0^{\mathrm{a}}$ \\
\hline Hum $_{\mathrm{BBCH} 23}$ & 8 & $3,991.0^{\mathrm{d}}$ & $4,998.0^{\mathrm{abc}}$ & $542.0^{\mathrm{a}}$ \\
\hline $\mathrm{Hum}_{\mathrm{BBCH} 23}+\mathrm{N}_{\mathrm{BBCH} 23}$ & 9 & $3,803.0^{\mathrm{ab}}$ & $4,956.0^{\mathrm{ab}}$ & $551.0^{\mathrm{a}}$ \\
\hline $\operatorname{Lig}_{\text {Aut }}+\mathrm{N}_{\mathrm{BBCH} 23}$ & 10 & $3,794.0^{\mathrm{ab}}$ & $4,912.7^{\mathrm{a}}$ & $538.0^{\mathrm{a}}$ \\
\hline$L S D_{0.05}$ & & 98.124 & 136.927 & 46.412 \\
\hline
\end{tabular}

Explanation: see Table 4 and 5 
The impact of application of lignite and sodium humate on the calcium content was not recorded, which is in accordance with the above mentioned authors Halčínová and Kováčik (2011).

The level of available phosphorus in soil is influenced positively by the quantity of humus acids, which create chelate bonds with mineral sorbents of the phosphoric ions, protecting in this way the water-soluble phosphorus against the reactions with calcium, iron, aluminium and heavy metals (Kováčik 2014). The data in Table 8 proves this fact completely. The application of coal materials into soil increased the content of available phosphorus in soil considerably (var. 2 and 3 ). The addition of nitrogen to these materials (var. 5 a 6 ) increased the content of movable $\mathrm{P}$ in the soil, which is related to the support of mineralization of organic compounds containing phosphorus after the application of the mineral nitrogen fertiliser into soil. The utilizations of only foliar treatments by sodium humate (var. 8, 9) did not have a significant impact on the content of available phosphorus in soil. Table 8 shows that the lowest content of available $\mathrm{P}$ was in the control variant. This implies that with the foliar application of sodium humate, a part of substance gets into soil and influences the soil chemism.

We have enriched the information about the existence of direct correlation between the quantity of applied manure and the quantity of available phosphorus in soil (Kováčik 2014) by the fact about positive correlation coefficient $r$ between the quantity of available phosphorus in soil and the content of total carbon in soil $\left(r=0.647^{+}\right)$.

The application of coal materials into soil (var. 2 and 3 ) increased the carbon content in soil, however, the increase was not considerable. The addition of nitrogen to lignite, or to sodium humate (var. 5 and 6) increased the carbon content significantly. Similarly, the independent application of commercial nitrogen fertiliser (var. 4 and 7) increased the quantity of carbon in the soil after harvest, which is a result of the positive impact of $\mathrm{N}$ not only on the aboveground phytomass (Table 8) but also on underground phytomass. Šimanský et al. (2008) also claim that after the application of commercial nitrogen fertilisers, the $\mathrm{C}_{\mathrm{ox}}$ content can be both decreased and increased in soil.

The application of sodium humate, lignite and nitrogen fertiliser into soil and also the application of sodium humate and $\mathrm{N}$ fertiliser on leaves had an impact on the value of soil reaction; they increased it (Table 8, var. $2-10$ ). The solo applications of sodium humate and DAM-390 into soil increased the $\mathrm{pH}$ value more than the application on leaves (var. 3 and 4 versus var. 7 and 8 ). The increase in $\mathrm{pH}$ values after the usage of sodium humate and also DAM-

T a b 1 e 8

The impact of lignite, sodium humate and nitrogen application on some soil parameters detected after finisching experiment in layer $0.0-0.3 \mathrm{~m}$ (dry mater - average of two years)

\begin{tabular}{|c|c|c|c|c|}
\hline \multicolumn{2}{|c|}{ Variant } & \multirow{2}{*}{$\begin{array}{c}\mathrm{P} \\
{[\mathrm{mg} / \mathrm{kg}]}\end{array}$} & \multirow{2}{*}{$\begin{array}{l}\mathrm{C}_{\text {ox }} \\
{[\%]}\end{array}$} & \multirow{2}{*}{$\mathrm{pH} / \mathrm{KCl}$} \\
\hline designation & number & & & \\
\hline 0 & 1 & $55.00^{\mathrm{a}}$ & $1.30^{\mathrm{a}}$ & $5.39^{\mathrm{a}}$ \\
\hline $\operatorname{Lig}_{\text {Aut }}$ & 2 & $72.00^{\mathrm{bc}}$ & $1.40^{\mathrm{ab}}$ & $5.42^{\mathrm{ab}}$ \\
\hline Hum $_{\text {Sow }}$ & 3 & $79.50^{\mathrm{bc}}$ & $1.34^{\mathrm{ab}}$ & $5.60^{\mathrm{abc}}$ \\
\hline $\mathrm{N}_{\text {Sow }}$ & 4 & $68.83^{\mathrm{ab}}$ & $1.43^{\mathrm{ab}}$ & $5.48^{\mathrm{ab}}$ \\
\hline $\mathrm{Hum}_{\text {Sow }}+\mathrm{N}_{\text {Sow }}$ & 5 & $86.75^{\mathrm{c}}$ & $1.47^{\mathrm{b}}$ & $5.73^{c}$ \\
\hline $\operatorname{Lig}_{\text {Aut }}+\mathrm{N}_{\text {Sow }}$ & 6 & $82.00^{\mathrm{bc}}$ & $1.50^{\mathrm{b}}$ & $5.52^{\mathrm{abc}}$ \\
\hline $\mathrm{N}_{\mathrm{BBCH} 23}$ & 7 & $57.75^{\mathrm{ab}}$ & $1.41^{\mathrm{ab}}$ & $5.43^{\mathrm{ab}}$ \\
\hline Hum $_{\text {BвCH23 }}$ & 8 & $55.17^{\mathrm{a}}$ & $1.30^{\mathrm{a}}$ & $5.58^{\mathrm{abc}}$ \\
\hline $\mathrm{Hum}_{\mathrm{BBCH} 23}+\mathrm{N}_{\mathrm{BBCH} 23}$ & 9 & $59.83^{\mathrm{ab}}$ & $1.31^{\mathrm{a}}$ & $5.64^{\mathrm{bc}}$ \\
\hline $\operatorname{Lig}_{\text {Aut }}+\mathrm{N}_{\mathrm{BBCH} 23}$ & 10 & $73.50^{\mathrm{bc}}$ & $1.42^{\mathrm{ab}}$ & $5.54^{\mathrm{abc}}$ \\
\hline$L S D_{0.05}$ & & 16.727 & 0.157 & 0.249 \\
\hline
\end{tabular}

Explanation: see Table 4 and 5 
390 were expected as these materials are alkalic. In the process of lignite application, the change was not expected because its $\mathrm{pH}$ value was almost the same as soil $\mathrm{pH}$ value. From a statistical viewpoint, the change did not happen. The difference was not significant. The considerable change of $\mathrm{pH}$ value appeared only in two variants, particularly in the case when apart from sodium humate, nitrogen was also applied (var. 5 and 9). This means that the significant change of soil $\mathrm{pH}$ value requires an abundant quantity of alkalic substances.

\section{CONCLUSIONS}

The autumn application of solid lignite and the pre-sowing application of solid sodium humate into soil tended to decrease the grain and straw yield of spring barley, content of crude protein in grain, proportion of the first-class grains and volume weight of grain. The impact of humate was more on the negative side; however, it was not significant statistically.

Lignite and sodium humate in solid form should be used along with nitrogen fertiliser.

The application of coal materials into soil increased the content of available phosphorus in soil significantly, and the carbon content insignificantly. The addition of nitrogen to these materials further increased the content of movable phosphorus and the total carbon in soil. We have detected a positive relationship between the quantity of the available phosphorus in soil and the content of total carbon in soil.

The application of sodium humate in liquid form during the growth season of spring barley tended to increase the grain and straw yield. The joint application of nitrogen and liquid sodium humate during the barley growth season increased the yield of barley grain significantly.

A lower dose of nitrogen, applied on barley leaves in growth phase $\mathrm{BBCH} 23$, increased the yield of barley grain considerably more than a higher $\mathrm{N}$ dose applied into the soil before barley sowing.

Acknowledgements. This paper was supported by VEGA project No. 1/0704/16.

\section{REFERENCES}

BIELEK, P. 1998. Dusík v pol'nohospodárskych pôdach Slovenska [Nitrogen in Slovakia agricultural soils]. Bratislava: VÚPÚ, 255 p. ISBN 80-85361-44-2.

CANDRÁKOVÁ, E. - SZOMBATHOVÁ, N. - SMATANA, J. 2009. The yield and quality of spring barley affected by nitrogen fertilization during growing period. In Research Journal of Agricultural Science, vol. 41 , no. 1 , pp. 16-21.

COOK, G.W. 1982. Fertilizing for maximum yield. $3^{\text {rd }}$ edition. Granada : LSBS, 465 p. ISBN 0246119047.

DZIADOWIEC, H. - GONET, S.S. 1999. Przewodnik metodyczny do badań materii organicznej gleb [Methodical guide-book for soil organic matter studies]. Prace Komisji Naukowych Polskiego Towarzystwa Gleboznawczego, N. 120, Komisja chemii gleb, Zespół Materii Organicznej Gleb, N II/16, 65 p.

FECENKO, J. - MALIŠ, L. - KOVÁČIK, P. 1995. Effects of sodium humate on the yield formation and quality of spring barley. In Zeszyty Problemowe Postepów Nauk rolniczych, vol. 421, pp. 31-36.

GILL, R.S. - LAVENDER, D.P. 1983. Urea fertilization and foliar nutrient composition of western hemlock (Tsuga heterophylla (Raf.) Sarc.). In Forest Ecology and Management, vol. 6, no. 4. pp. 333-341.

HALČÍNOVÁ, M. - KOVÁČIK, P. 2011. Využitie pevného humátu sodného a lignofertu vo výźive jačmeña jarného (Hordeum vulgare, L.) [Utilize of solid sodium humate and Lignofert at spring barley nutrition (Hordeum vulgare, L.)]. Nitra : SPU v Nitre, 76 pp. ISBN 978-80-552-0636-3.

CHEN, Z. - WANG, H. - LIU, X. - LIU, Y. - GAO, S. - ZHOU, J. 2016. The effect of $\mathrm{N}$ fertilizer placement on the fate of urea- ${ }^{15} \mathrm{~N}$ and yield of winter wheat in southeast China. In PLoS One, vol. 11, no. 4, pp. e0153701 http://dx.doi.org/10.1371/journal. pone. 0153701

KANDERA, M. 1994. Účinok hnojenia dusíkom na úrody zma jarného jačmeňa a jeho kvalitu [Impact of nitrogen fertilization on the yield of spring barley and its quality]. In Rostlinná výroba, vol. 40, no. 7, pp. 577-585.

KOVÁČIK, P. - FECENKO, J. 1992. Metodické prístupy k výpočtu dávky dusíka pre sladovnícky jačmeň [Methodical approaches to calculation of nitrogen dosage for malt barley]. In Agrochémia, vol. 32, no. 3, pp. 54-55.

KOVÁČIK, P. - FECENKO, J. 1996. Pôdny dusík, humát sodný a parametre úrody jarného jačmeňa [Soil nitrogen, sodium humate and yield parameters of spring barley]. In Polnohospodárstvo, vol. 42, no. 5, pp. 334-343.

KOVÁČIK, P. 1997. Rozbory pôd, rastlin, hnojiv a výpočet dávok živín $k$ pol’ným a záhradným plodinám [Analysis of soils, plants, fertilizers and calculation of dosages of nutrients for field and garden plants]. Nitra: SPU, pp. 99. ISBN 80-7137-355-9

KOVÁČIK, P. - JANČOVIČ, J. - TOMÁŠ, J. 2006. Hnojenie jačmeňa jarného dusíkom počas odnožovania [Nitrogen fertilization of spring barley at tillering 
stage]. In Agriculture (Pol'nohospodárstvo), vol. 52, no. 2 , pp. $77-86$

KOVÁČIK, P. - JASIEWICZ, Cz. 2009. Risks of heavy metals entrance into soil and plants after chemically and mechanically treated coal application. In Ecological chemistry and engineering A, vol. 16, no. 12, pp. $1577-1584$

KOVÁČIK, P. 2014. Princípy a spôsoby výživy rastlín [The principles and ways of plant nutrition]. Nitra : SPU v Nitre, 278 pp. ISBN 978-80-552-1193-0.

LEE, Y.S. - BARTLETT, R.J. 1976. Stimulation of plant growth by humic substances 1. In Soil Science Society of America Journal, vol. 40, no. 6, pp. 876-879.

LOBARTINI, J.C. - TAN, K.H. - REMA, J.A. - GINGLE, A.R. - PAPE,C. - HIMMELSBACH, D.S. 1992. The geochemical nature and agricultural importance of commercial humic matter. In The science of the total environment, vol. 113, no. 1-2, pp. 1-5.

MEHLICH, A. 1984. Mehlich 3 soil test extractant: A modification of Mehlich 2 extractant. In Communication in Soil Science and Plant Analysis, vol. 15, pp. 1409-1416.

PATIL, R.B. - KADAM, A.S. - WADJE, S.S. 2011. Role of potassium humate on growth and yield of soybean and black gram. In International Journal of Pharma and Bio Sciences, vol. 2, no. 1, pp. B242-B246.

SHALABEY, O. - BIZÍK, J. 1998. Effects of manure, sodium humate and nitrogen on the content of some heavy metals in spring wheat. In Polnohospodárstvo, vol. 44 , no. 4 , pp. 263-274.

ŠIMANSKÝ, V. - TOBIAŠOVÁ, E. - CHLPÍK, J. 2008. Soil tillage and fertilization of Orthic Luvisol and their influence on chemical properties, soil structure stability and carbon distribution in water-stable macro-aggregates. In Soil \& Tillage Research, vol. 100 , pp. $125-132$.
ŠKARPA, P. 2006. Vliv zásoby živin v půdě a úrovně hnojení na produkční ukazatele ječmene jarního (Hordeum Vulgare L.) [The soil nutrient content effect and level of fertilizing on the yield of spring barley]. In Acta universitatis agriculturae et silviculturae mendelianae brunensis, vol. 54, no. 4, pp. 91-98.

ŠREK, P. - KUNZOVÁ, E. 2011. Effect of long-term N, $\mathrm{P}$ and $\mathrm{K}$ fertilizer application on the grain yield of spring barley grown in different soil and climate conditions: Results from Čáslav, Lukavec and Ivanovice 2005-2008. In Agriculture (Pol'nohospodárstvo), vol. 57, no. 1 , pp. $12-20$.

UŽÍK, M. - ŽOFAJOVÁ, A. 2006. Reaction of spring barley genotypes on nitrogen fertilization in grain yield and quality traits in generations F3, F4 and F5. In Agriculure (Pol'nohospodárstvo), vol. 52, no 1, pp. 24-37.

UŽÍK, M. - ŽOFAJOVÁ, A. - HANKOVÁ, A. 2009. Breeding progress in grain yield and quality of winter wheat cultivars. In Agriculture (Polnohospodárstvo), vol. 55 , no.1, pp. 26-32.

VANEKOVÁ, Z. - VANEK, G. 1983. Hnojenie [Fertilizing] 1. vyd., Bratislava: Príroda, pp. 107.

VALŠÍKOVÁ, M. - VITEKOVÁ, A. 2006. The effect of Lignofert organic fertilizer on formation and quality of head lettuce yield. In Horticultural Science (Prague), vol. 33, no. 3, pp. 114-118.

WEISMANN, L. - BAKOŠ, D. - EMRICH, J. - KRÁL'OVIČ, J. 1993. Ekofert - ekologický a ekonomický príspevok pre súčasné pol'nohospodárstvo. In Naturalium, no. 5, pp. 5-8.

IUSS Working Group WRB. 2006. World reference base for soil resources 2006. 2nd edition. World Soil Resources Reports No. 103. Rome: FAO, pp. 145.

Received: July 20, 2016 